\title{
Age- and weight-dependent susceptibility of rainbow trout Oncorhynchus mykiss to isolates of infectious haematopoietic necrosis virus (IHNV) of varying virulence
}

\author{
Sven M. Bergmann ${ }^{1, *}$, Dieter Fichtner ${ }^{1}$, Helle Frank Skall ${ }^{2}$, \\ Hans-Jürgen Schlotfeldt ${ }^{3}$, Niels Jørgen Olesen ${ }^{2}$ \\ ${ }^{1}$ Federal Research Centre for Virus Diseases of Animals, Boddenblick 5a, 17493 Greifswald - Insel Riems, Germany \\ ${ }^{2}$ Danish Veterinary Institute, Hangovej 2, 8200 Århus, Denmark \\ ${ }^{3}$ State Fish Epidemics Control and Fish Health Service of Lower Saxony, Eintrachtweg 17, 30173 Hannover, Germany
}

\begin{abstract}
The virulence of 5 European and 1 North American isolate of infectious haematopoietic necrosis virus (IHNV) was compared by infecting female sibling rainbow trout ('Isle of Man' strain) of different weights and ages $(2,20$ and $50 \mathrm{~g})$. The fish were exposed to $10^{4} \mathrm{TCID}_{50} \mathrm{IHNV}$ per ml of water by immersion, and the mortality was recorded for $28 \mathrm{~d}$. Two new IHNV isolates from Germany were included in the investigation. One was isolated from European eels kept at $23^{\circ} \mathrm{C}\left( \pm 2^{\circ} \mathrm{C}\right)$ and the other was not detectable by immunofluorescence with commercially available monoclonal antibodies recognising the viral G protein. The results showed that IHNV isolates of high or low virulence persisted in rainbow trout of all ages/weights for $28 \mathrm{~d}$, with the exception of fish over $15 \mathrm{~g}$ in the eel IHNV (DF [diagnostic fish] 13/98)-infected groups from which the virus could not be reisolated on Day 28. The smallest fish were most susceptible to an infection with any of the IHNV isolates. The lowest cumulative mortality (18\%) was observed in fingerlings infected with the North American isolate HAG (obtained from Hagerman Valley), and the highest mortality (100\%) in DF 04/99 infected fish. The DF 04/99 and Ö-13/95 viruses caused mortality in fish independent of their weight or age. The isolates FR-32/87 and I-4008 were virulent in fish up to a weight of $20 \mathrm{~g}$ and caused no mortality in larger fish. In the IHNV HAG- and DF 13/98 (eel)-infected rainbow trout, no signs of disease were observed in fish weighing between 15 and $50 \mathrm{~g}$. An age/weight related susceptibility of rainbow trout was demonstrated under the defined conditions for all IHNV isolates tested.
\end{abstract}

KEY WORDS: Susceptibility $\cdot$ Infectious haematopoietic necrosis $\cdot$ IHN $\cdot$ Infectious haematopoietic necrosis virus $\cdot \mathrm{IHNV} \cdot$ Virulence differences $\cdot$ Rainbow trout

Resale or republication not permitted without written consent of the publisher

\section{INTRODUCTION}

Infectious haematopoietic necrosis (IHN) and viral haemorrhagic septicaemia (VHS) are rhabdoviral diseases of rainbow trout Oncorhynchus mykiss which are of high economic importance. In Europe IHN was first detected in France (Baudin Laurencin 1987) and Italy (Bovo 1987) in 1987, and in Germany in 1992 (Enzmann et al. 1992). IHN virus (IHNV) often was isolated from farms where the fish were chronically infected but did not show abnormal mortality or clinical signs of the disease. Some salmonids probably are genetically more resistant to IHNV or VHS virus (VHSV) than others (LaPatra et al. 1994, Trobridge et al. 2000, Quillet et al. 2001). Furthermore, the virulence of IHNV isolates varies in different species of fish (LaPatra et al. 1990a,b, 1993, Basurco et al. 1993).

The manifestation of IHN disease also depends on the size/age of the fish, water temperature, season and environmental conditions - factors which can all 
heavily affect the immune response in fish (LaPatra 1998). In this study, rainbow trout resistant to a waterborne VHSV infection were kept under defined conditions and were infected with European and North American isolates of IHNV. The aims of this study were to determine the virulence of the different isolates and to compare the virulence of individual isolates in fish of different sizes and ages.

\section{MATERIALS AND METHODS}

Cell culture and viruses. Epithelioma papulosum cyprini (EPC) cells (Fijan et al. 1983) were grown in $75 \mathrm{~cm}^{2}$ flasks (Sarstedt USA) at $26^{\circ} \mathrm{C}$ for $1 \mathrm{~d}$ and were then transferred to $15^{\circ} \mathrm{C}$. Five IHNV isolates (Table 1) at low cell culture passages (9 to 11) were propagated in EPC cell monolayers at $15^{\circ} \mathrm{C}$ and 1 isolate (obtained from European eel Anguilla anguilla) was propagated at $20^{\circ} \mathrm{C}$. Each isolate was harvested after 4 to $6 \mathrm{~d}$ post infection (p.i.), frozen once at $-20^{\circ} \mathrm{C}$, and titrated 3 times in EPC cells. All European virus isolates descended from outbreaks with symptoms and heavy losses (DF 13/98, Ö-13/95, FR-32/87), some of up to $100 \%$ (DF 04/99, I-4008). The American IHNV isolate HAG (LaPatra et al. 1990a,b) was found to be virulent in steelhead trout Oncorhynchus mykiss, kokanee $O$. nerka and chinook O. tshawatscha of different ages and weights (LaPatra et al. 1990a,b, 1993).

Fish and schedules of the infection trials. Female rainbow trout Oncorhynchus mykiss of the Isle of Man strain were obtained from a commercial hatchery free from infectious pancreatic necrosis virus, VHSV, IHNV and Aeromonas salmonicida salmonicida, and were kept in $400 \mathrm{l}$ tanks with a circulating freshwater system $\left(1.8 \mathrm{~m}^{3} \mathrm{~h}^{-1}\right)$ and $40 \mathrm{l}$ water exchange per day at $9 \pm 1^{\circ} \mathrm{C}$. Commercially available rainbow trout food suitable for fish of each size and age was used. Small fish up to a weight of $10 \mathrm{~g}$ were fed 4 times daily. Feeding of larger fish was reduced to twice daily. The fish were raised from $2 \mathrm{~g}$ to a weight of $50 \mathrm{~g}$ under these defined conditions. After a 2 wk adaptation period, duplicate groups of fish weighing 2.5 to $3 \mathrm{~g}$ $(\mathrm{n}=40)$ were infected by immersion in $10^{4} \mathrm{TCID}_{50}$ $\mathrm{ml}^{-1}$ of each IHNV isolate for $1 \mathrm{~h}$. Thereafter, the fish were held at a water temperature of $9^{\circ} \mathrm{C}\left( \pm 1^{\circ} \mathrm{C}\right)$ for $28 \mathrm{~d}$. All infected survivors were anaesthetised with $2 \%$ Benzocaine in water and killed by decapitation. Virus reisolation from organ pools (spleen, heart, kidney) of individual dead fish was carried out in EPC cells and virus was identified by immunofluorescence according to Commission Decision 96/240/EC (Anonymous 1992, Fichtner et al. 2000). Two months later, duplicate groups of fish grown up to $15-20 \mathrm{~g}$ (n =15) were infected by immersion with the same IHNV isolates under identical conditions as described above. Siblings $(n=20)$ from the same stock were also infected by immersion when they had reached a weight of 40 to $50 \mathrm{~g}$. For each experiment, negative control fish were kept separately from the infection trials, but under the same conditions.

Virus identification. Prior to the infection trials, all IHNV isolates were identified according to Commission Decision 96/240/EC (Anonymous 1992) by immunofluorescence with monoclonal antibodies recognising the viral G (Fichtner et al. 2000) or N protein (Bergmann et al. 2002), especially for the German isolate DF 04/99. Virus was reisolated in EPC cells from pooled organs of fish that had died during the experiments and from survivors on Day 28 p.i., and subsequently were identified by immunofluorescence or the virus neutralisation test using neutralising rabbit antisera from the CRL (Community Reference Laboratory for Fish Diseases, Århus, Denmark).

Statistical analysis. The $\chi^{2}$ test $(p<0.05)$ was used to show significant differences in cumulative mortality induced by the virulence of each IHNV isolate. In the groups of fish with 15 to 20 and 40 to $50 \mathrm{~g}$ body weight, the Yates correction was used for determining the significance of $\chi^{2}$ for data with small values ( $\mathrm{n}$ " 60) (Yates 1984).

Table 1. Isolates of infectious haematopoietic necrosis virus (IHNV) used to compare virulence by infecting female sibling rainbow trout Oncorhynchus mykiss. Stock virus titration according to Spearman \& Kaerber (Kaerber 1931). EPC: Epithelioma papulosum cyprini

\begin{tabular}{|lcclclll}
\hline Isolate & Country of origin & $\begin{array}{c}\text { Year of } \\
\text { isolation }\end{array}$ & Host species & $\begin{array}{c}\text { Total passages } \\
\text { in EPC cell }\end{array}$ & Stock virus titre & Source \\
\hline HAG & USA & 1983 & Rainbow trout & 11 & $10^{7.75} \mathrm{TCID}_{50} \mathrm{ml}^{-1}$ & LaPatra et al. (1990b) \\
FR-32/87 & France & 1987 & Rainbow trout & 11 & $10^{7.0} \mathrm{TCID}_{50} \mathrm{ml}^{-1}$ & Baudin Laurencin (1987) \\
I-4008 & Italy & 1987 & Rainbow trout & 10 & $10^{7.25} \mathrm{TCID}_{50} \mathrm{ml}^{-1}$ & Bovo et al. (1987) \\
DF 04/99 & Germany & 1999 & Rainbow trout & 10 & $10^{7.0} \mathrm{TCID}_{50} \mathrm{ml}^{-1}$ & Fichtner et al. (2000) \\
DF 13/98 & Germany & 1998 & European eel & 9 & $10^{7.0} \mathrm{TCID}_{50} \mathrm{ml}^{-1}$ & Bergmann et al. (2002) \\
Ö-13/95 & Austria & 1995 & Rainbow trout & 8 & $10^{7.5} \mathrm{TCID}_{50} \mathrm{ml}^{-1}$ & Bergmann et al. (2002) \\
\hline
\end{tabular}



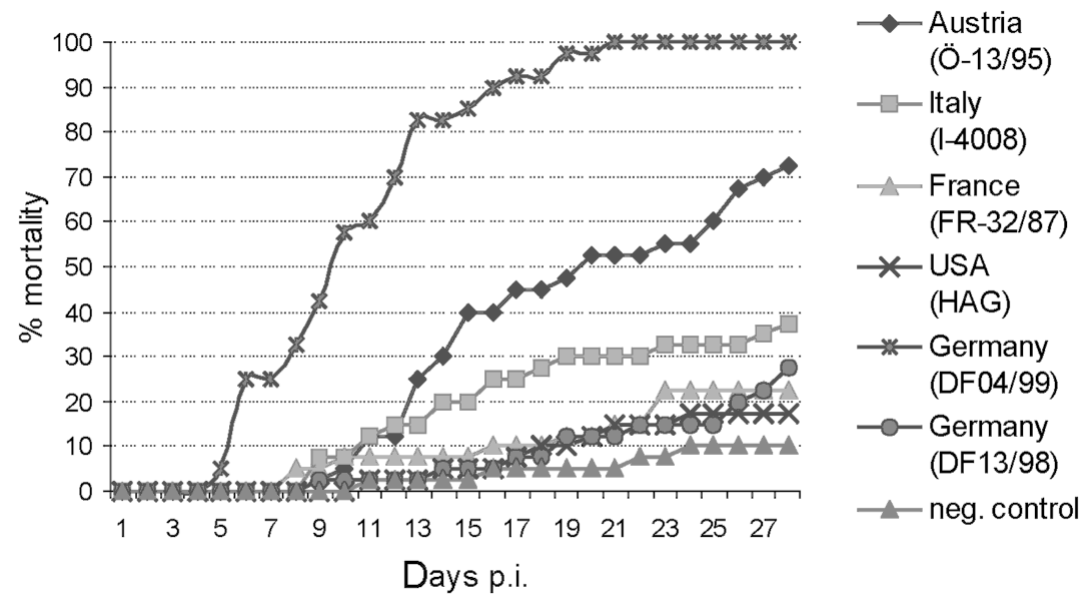

Fig. 1. Oncorhynchus mykiss. Cumulative mortality of rainbow trout fingerlings (2.5 to $3.0 \mathrm{~g}$ ) infected with different infectious haematopoietic necrosis virus (IHNV) isolates. See Table 1 for details of isolates

\section{RESULTS}

\section{Rainbow trout weighing 2.5 to $3 \mathrm{~g}$}

Mortality started on Day 4 p.i. in fish infected with the German IHNV isolate DF 04/99. The DF 04/99-infected rainbow trout showed typical clinical signs, e.g. apathy without food intake, dark colouration of the skin, ascites and exophthalmus. In the tanks where rainbow trout infected with the other 5 IHNV isolates were kept, the first dead fish were observed between Days 6 and 10 p.i. Clinical signs of IHN were observed in fish infected with the Austrian IHNV isolate Ö-13/95, the French isolate FR-32/87 and the Italian isolate I-4008. Additionally, isolate FR-32/87 was the only one that induced petechial haemorrhages in the skin. However, no clinical signs were observed following infection with isolate DF 13/98 from European eel and with the USA isolate HAG. The highest mortality was found in the groups of fish infected with the German isolate DF 04/99, of which $100 \%$ died within $18 \mathrm{~d}$ (Fig. 1). The Austrian isolate Ö-13/95 had induced a mortality of $73 \%$ by Day 28 p.i. A considerably lower mortality was caused by the IHNV isolates obtained from Italy $(38 \%)$, France $(23 \%)$ and the USA (18\%). The German eel isolate DF 13/98 killed $28 \%$ of the rainbow trout fingerlings. At the end of the experiment (Day 28) all IHNV isolates were detected and identified from organ pools of the survivors, except from pools of trout infected with DF 13/98 virus. A significant difference in mortality compared to the control groups occurred in fish infected with isolates DF 04/99, I-4008, Ö-13/95 and DF 13/98.

\section{Rainbow trout weighing 15 to $20 \mathrm{~g}$}

Six days after infection by immersion, mortality was observed in the groups of fish infected with the German IHNV isolate DF 04/99. Mortality occurred on Days 10 and 16 p.i. in fish infected with the Austrian isolate Ö-13/95 and with the French isolate FR-32/87, respectively. By Day 28 p.i., the German isolate DF 04/99 had caused $53 \%$ mortality; the Austrian isolate Ö-13/95, $23 \%$; and the French isolate FR-32/87, 8\% (Fig. 2). None of the other isolates induced symptoms or mortality. Severe clinical signs of IHN only were observed in fish infected with isolate DF 04/99.

The viruses were reisolated from fish infected with all of the IHNV isolates except for fish infected with the German eel isolate DF 13/98 sampled on Day 28 p.i.

A significant difference in mortality compared to the control groups was only observed in fish infected with isolate DF 04/99.

\section{Rainbow trout weighing 40 to $50 \mathrm{~g}$}

Again, the German IHNV isolate DF 04/99 induced severe clinical signs of IHN and the highest cumulative mortality (20\%), after $28 \mathrm{~d}$. The Austrian isolate Ö-13/95

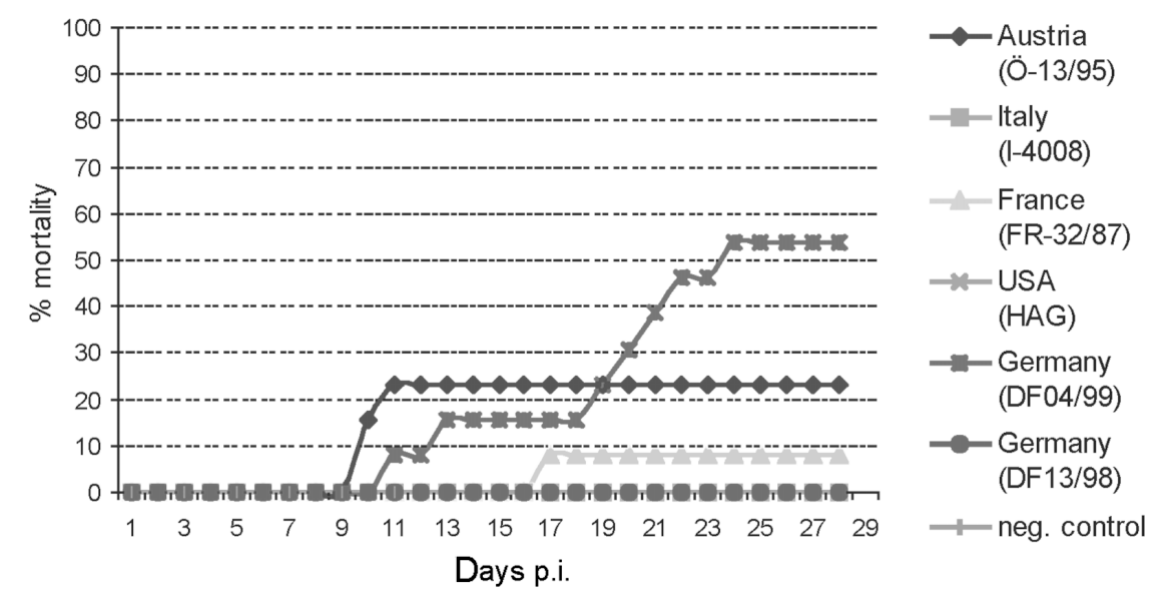

Fig. 2. Oncorhynchus mykiss. Cumulative mortality of rainbow trout (15 to $20 \mathrm{~g}$ ) infected with different infectious haematopoietic necrosis virus (IHNV) isolates. See Table 1 for details of isolates 


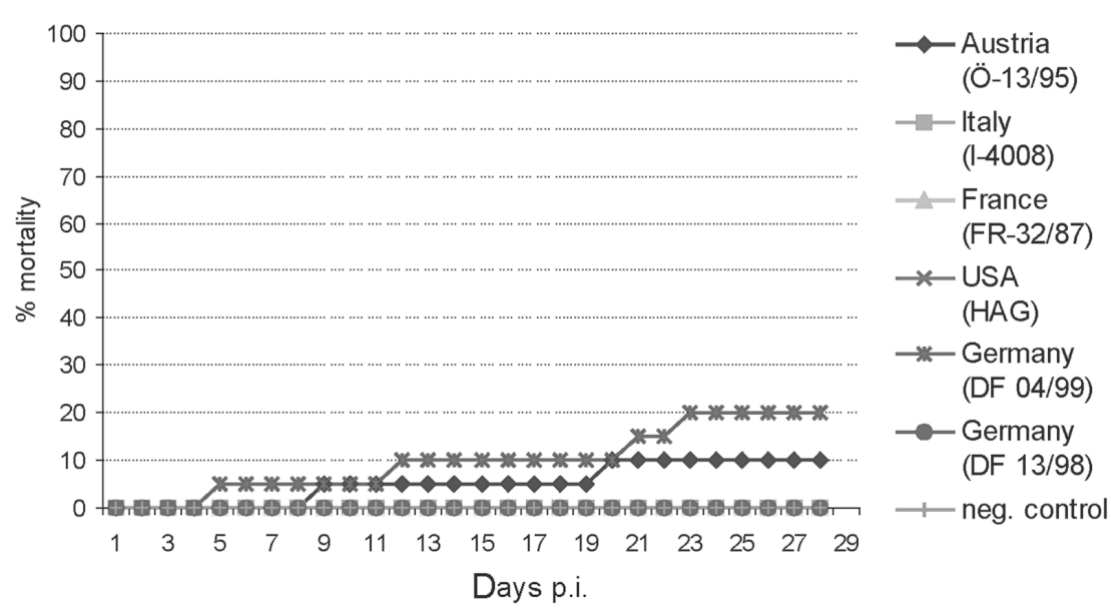

Fig. 3. Oncorhynchus mykiss. Cumulative mortality of rainbow trout (40 to $50 \mathrm{~g}$ ) infected with different infectious haematopoietic necrosis virus (IHNV) isolates. See Table 1 for details of isolates

caused a mortality of $10 \%$ (Fig. 3). In each of the groups infected with the Italian isolate I-4008, the German eel isolate DF 13/98, and the French isolate FR-32/87, 1 fish died before Day 3, without any clinical sign of disease. In contrast to all other dead fish, neither virus nor pathogenic bacteria and general parasites were detectable. Therefore, those fish were not included in the calculation of the cumulative mortality. Neither IHNV-induced mortality nor clinical signs of IHN were observed in fish infected with HAG (USA), FR-32/87 (France), I-4008 (Italy) or DF 13/98 (Germany).

At the end of the experiment (Day 28), IHNV could not be detected in fish infected with the German eel isolate DF 13/98. However, IHNV was identified by immunofluorescence in the organ pools of all other survivors.

A significant difference in mortality compared to the control group of the same weight and age was only observed in fish infected with isolate DF 04/99.

\section{DISCUSSION}

Antigenic relationships, differences in virulence and electropherotyping of the $\mathrm{N}$ proteins among North American IHNV isolates have been reported (Rucker et al. 1953, McCain et al. 1971, LaPatra et al. 1993, 1994). However, no information is available on differences in virulence between European IHNV isolates in fish of different ages and sizes. For these experiments the 'Isle of Man' rainbow trout strain was selected because of its low susceptibility to a waterborne VHSV infection $\left(10^{4} \mathrm{TCID}_{50} \mathrm{ml}^{-1}\right)$ (data not shown). The results of these experiments confirmed and expanded the results of LaPatra et al. (1990a,b, 1991, 1993, 1994). In fish of all ages and weights, larger differences in virus virulence were observed after waterborne infection with the selected IHNV isolates (5 European and 1 North American), although the cumulative mortality decreased with increasing age/weight of the fish. In all 3 groups the highest mortality was induced by the German isolate DF 04/99 (Fig. 4). The virus had killed $100 \%$ of the 2.5 to $3 \mathrm{~g}$ fish, $53 \%$ of the $20 \mathrm{~g}$ fish and $20 \%$ of the $50 \mathrm{~g}$ fish by Day 28 p.i. This virus isolate was also the only one that was not detectable by immunofluorescence with commercially available MAbs directed against the G protein (Fichtner et al. 2000). It is presumably a new variant which contains changes in the amino acid sequence of the $\mathrm{G}$ protein. In contrast, all viruses were identified by immunofluorescence using MAbs against the N protein (Bergmann et al. 2002).

Fish infected with the Austrian isolate Ö-13/95 succumbed to the virus in the same way as they did to isolate DF 04/99, but the former isolate induced a relatively lower cumulative mortality. In fingerlings, a cumulative mortality of $72 \%$ occurred. When the fish had grown to larger sizes, the cumulative mortality decreased to $23 \%$ in fish of $20 \mathrm{~g}$ and to $10 \%$ in fish of $50 \mathrm{~g}$.

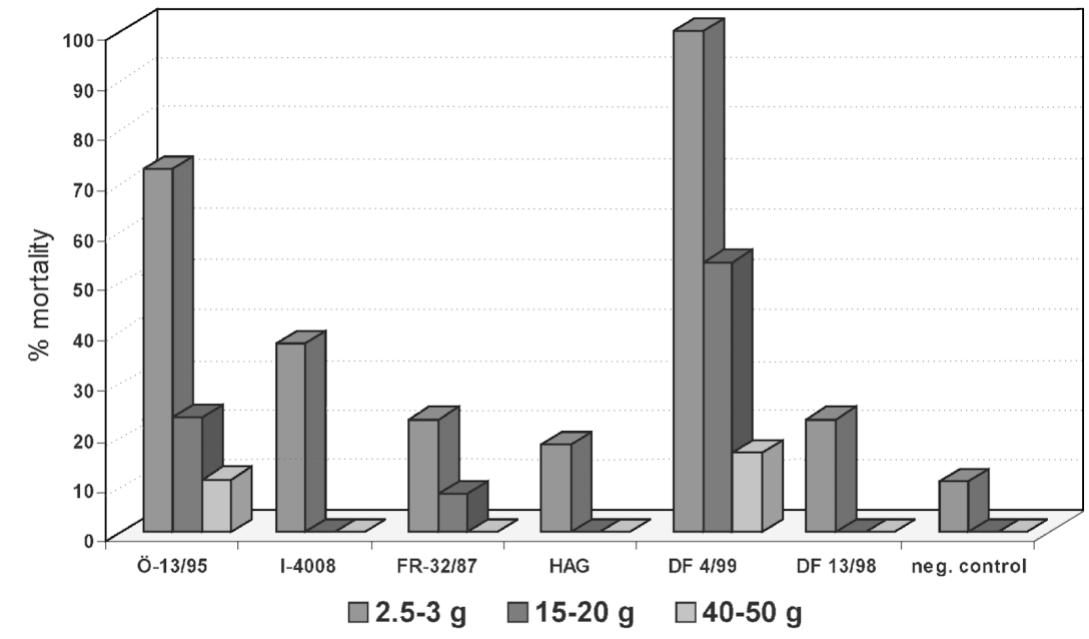

Fig. 4 Oncorhynchus mykiss. Comparison of cumulative mortality (\%) of fish infected with 5 European infectious haematopoietic necrosis virus (IHNV) isolates and 1 North American IHNV isolate at $28 \mathrm{~d}$ post infection 
This pattern of mortality, decreasing with increasing size or age, also occurred in experiments with the other isolates, although the observed mortality rates were lower. No mortality occurred in fish of $50 \mathrm{~g}$ infected with the Italian and the French IHNV isolates.

In all groups, the lowest mortality occurred when the USA isolate HAG and the German isolate DF 13/98 were used for infection of fish. In fingerlings, a very low mortality was caused by these 2 isolates, and no mortality occurred in larger fish. This contradicts the findings of LaPatra et al. (1990a,b), where a higher HAG-induced mortality in smaller and larger rainbow trout was observed. This can be explained by the serial passage of the HAG virus (11 passages) in a nonsalmonid cell line (EPC) and the obviously natural resistance of the Isle of Man rainbow trout strain to IHNV infection. The same considerations also might apply to the French (FR-32/87) and Italian (I-4008) isolates.

With the exception of fish infected with German eel isolate DF 13/98, all viruses could be reisolated in EPC cells from fish that had died by, or were sampled on, Days 7 and 28. It was not possible to reisolate virus from fish infected with the German eel isolate DF 13/98 on Day 28 p.i., but on Day 7 p.i. the virus was isolated in EPC cells at a low titre $\left(10^{1} \mathrm{TCID}_{50} \mathrm{ml}^{-1}\right)$. These differences between the isolates were reflected in vitro since the DF $13 / 98$ replicated poorly at $15^{\circ} \mathrm{C}$, but very well at $20^{\circ} \mathrm{C}$ in EPC cells, and did not replicate in cells of rainbow trout origin such as the rainbow trout gonad (RTG-2) cell line (data not shown). The replication rate of this isolate in fish kept at $10^{\circ} \mathrm{C}$ and in cells incubated at $15^{\circ} \mathrm{C}$ obviously was very low. Thus, DF $13 / 98$ seems to be a representative of a new type of IHNV found in Europe.

The cumulative mortality was significantly different from the control groups $(\mathrm{p}<0.05)$ in all groups $(2.5$ to $50 \mathrm{~g})$ infected with DF $04 / 99$ and in the fingerling groups (2.5 to $3 \mathrm{~g}$ ) infected with Ö-13/95, I-4008 and DF 13/98.

Further studies should focus on antigenic and genetic differences of the virus G protein, which contains the neutralising epitopes and which, to all appearances, is responsible for the virulence of the virus (Engelking \& Leong 1989). The highly virulent isolate DF 04/99 or the 'exotic' DF 13/98 eel isolate should be given priority. For diagnostic purposes, the $\mathrm{N}$ gene and the viral $\mathrm{N}$ protein have to be included in the investigation with the aim of identifying newly emerging viruses. This information will be important for the understanding of viral pathogenesis and immunogenesis in fish, for the development of effective vaccines and for the reproducibility of IHNV challenge models or investigations on virus virulence.
Acknowledgements. We wish to thank Dr. Ellen Ariel and Dr. Peter Dixon for their critical review of the manuscript. The authors also thank Ms. Irina Werner and Ms. Sanne Madson for their excellent technical assistance.

\section{LITERATURE CITED}

Anonymous (1992) Commission Decision 92/532/EEC (Official Journal L 337, 21.11. 1992). Commission Decision of 19 November 1992 laying down the sampling plans and diagnostic methods for the detection and confirmation of certain fish diseases. This Decision was amended by Commission Decision 96/240/EC (Official Journal L 79, 29. 03. 1996)

Basurco B, Yun S, Hedrick RP (1993) Comparison of selected strains of infectious hematopoietic necrosis virus (IHNV) using neutralizing trout antisera. Dis Aquat Org 15:229-233

Baudin Laurencin F (1987) IHN in France. Bull Eur Assoc Fish Pathol 7:104

Bergmann SM, Ariel E, Skall HF, Fichtner D, Schlotfeldt HJ, Olesen NJ (2002) Vergleich von Methoden zum Nachweis einer Infektion mit verschiedenen Isolaten des Virus der Infektiösen Hämatopoetischen Nekrose (IHNV). Berl Muench Tieraerztl/Wochenschr 115:1-5

Bovo G, Giorgetti G, Jørgensen PEV, Olesen NJ (1987) Infectious haematopoietic necrosis: first detection in Italy. Bull Eur Assoc Fish Pathol 7:124

Engelking HM, Leong JC (1989) The glycoprotein of infectious hematopoietic necrosis virus elicits neutralizing antibodies and protective response. Virus Res 13: $213-230$

Enzmann PJ, Dangschat H, Feneis B, Schmitt D, Wizigmann G, Schlotfeldt HJ (1992) Demonstration of IHN virus in Germany. Bull Eur Assoc Fish Pathol 12:185

Fichtner D, Bergmann S, Enzmann PJ, Granzow H, Schütze H, Mock D, Schäfer JW (2000) Isolation and characterisation of a variant strain of infectious haematopoietic necrosis (IHN) virus. Bull Eur Assoc Fish Pathol 20:135-142

Fijan N, Sulimanovic D, Bearzotti M, Muzinic D, Zwillenberg LD, Chilmonczik S, Vautherot JF, de Kinkelin P (1983) Some properties of the Epithelioma papulosum cyprini (EPC) cell line from carp Cyprinus carpio. Ann Virol (Inst Pasteur) 134:207-220

Kaerber G (1931) Beitrag zur kollektiven Behandlung pharmakologischer Reihenversuche. Arch Exp Pathol Pharmakol 162:480

LaPatra SE (1998) Factors affecting pathogenicity of infectious hematopoietic necrosis virus (IHNV) for salmonid fish. J Aquat Anim Health 10:121-131

LaPatra SE, Groff JM, Fryer JL, Hedrick RP (1990a) Comparative pathogenesis of three strains of infectious hematopoietic necrosis virus in rainbow trout Oncorhynchus mykiss. Dis Aquat Org 8:105-112

LaPatra SE, Groberg WJ, Rohovec JS, Fryer JL (1990b) Size-related susceptibility of salmonids to two strains of infectious hematopoietic necrosis virus. Trans Am Fish Soc 119: 25-30

LaPatra SE, Lauda KA, Morton AW (1991) Antigenic and virulence comparison of eight isolates of infectious hematopoietic necrosis virus from the Hagerman Valley, Idaho, USA. In: Fryer JL (ed) Proc 2nd Int Symp Viruses of Lower Vertebrates. Oregon State University, Corvallis, OR, p 125-132

LaPatra SE, Fryer JL, Rohovec JS (1993) Virulence comparison of different electropherotypes of infectious hematopoietic necrosis virus. Dis Aquat Org 16:115-120 
LaPatra SE, Parsons JE, Jones GR, McRoberts WO (1994) Early life stage survival and susceptibility of brook trout, coho salmon, rainbow trout, and their reciprocal hybrids to infectious hematopoietic necrosis virus. J Aquat Anim Health 5:270-274

McCain BB, Fryer JL, Pilcher KS (1971) Antigenic relationship in a group of three viruses of salmonid fish by cross neutralisation. Proc Soc Exp Biol Med 137:1042-1046

Quillet E, Dorson M, Aubard G, Torhy C (2001) In vitro viral haemorrhagic septicaemia virus replication in excised fins of rainbow trout: correlation with resistance to waterborne

Editorial responsibility: Jo-Ann Leong,

Kaneohe, Hawaii, USA challenge and genetic variation. Dis Aquat Org 45: 171-182

Rucker RR, Whippel WJ, Parvin JR, Evan CA (1953) A contagious disease of salmon possibly of virus origin. Fish Bull Fish Wildl Serv US 54:35-46

Trobridge GD, LaPatra SE, Kim CH, Leong JC (2000) Mx mRNA expression and RFLP analysis of rainbow tout Oncorhynchus mykiss genetic crosses selected for susceptibility or resistance to IHNV. Dis Aquat Org 40:1-7

Yates FJ (1984) Tests of significance for $2 \times 2$ contingency tables. J R Stat Soc Ser A 147:426-463

Submitted: February 10, 2003; Accepted: January 13, 2003 Proofs received from author(s): July 8, 2003 